\title{
Kronik Olarak İntraserebroventriküler Enjekte Edilen Histamin ve Antagonistlerinin Hipotalamo-Hipofizer-Aks Üzerindeki Etkisi
}

\author{
Burçin ALTINBAŞ ${ }^{1,3}$, Gökçen GÜVENÇ BAYRAM ${ }^{2,3}$, Murat YALÇIN ${ }^{3}$ \\ 1 SANKO Üniversitesi Tıp Fakültesi Fizyoloji Anabilim Dalı, Gaziantep. \\ 2 Dokuz Eylül Üniversitesi Veteriner Fakültesi Fizyoloji Anabilim Dalı, İzmir. \\ 3 Bursa Uludağ Üniversitesi Veteriner Fakültesi Fizyoloji Anabilim Dalı, Bursa.
}

\section{ÖZET}

Merkezi sinir sistemi içerisinde nörotransmitter ve nöromodülatör etkiye sahip histamin, davranış durumunun, biyolojik ritmin, vücut ağırlığının, enerji metabolizmasının, termoregülasyonun, sıvı dengesinin, stresin ve üremenin düzenlenmesinde anahtar role sahiptir. Histaminin merkezi akut enjeksiyonlarının hipotalamo-hipofizer-gonadal (HPG) aks içerisinde etkili olduğunu ve histaminin merkezi $\mathrm{H}_{1}$ ve $\mathrm{H}_{2}$ reseptörlerinin bu etkiye aracılık ettiğini gösterdik. Fakat çalışmalarda, histaminin ve histamin reseptör antagonistlerinin uzun süreli merkezi tedavilerinin HPG aks içerisindeki etkilerine dair açıklayıcı bir bilgi bulunmamaktadır. Çalışmada, kronik olarak intraserebroventriküler (i.s.v.) enjekte edilen histamin ve antagonistlerinin hipotalamo-hipofizer-gonadal (HPG) aksta rol oynayan, gonadotropin salgılatıcı hormonun (GnRH), folikül stimüle edici hormonun (FSH), lüteinleştirici hormonun (LH) ve testosteron hormonunun plazma seviyelerine etkileri araştrılmıştır. Çalışma Sprague-Dawley ırkı sıçanlarda gerçekleştirilmiş̧ir. Histamin (100 nmol), histaminerjik H1 reseptör antagonisti klorfeniramin (100 nmol), histaminerjik H2 reseptör antagonisti ranitidin (100 nmol) veya histaminerjik H3/H4 reseptör antagonisti tiyoperamid (100 nmol) i.s.v. olarak 7 gün boyunca enjekte edilmiştir. Histamin ve antagonistlerinin kronik enjeksiyonu GnRH'nın plazma seviyelerinde anlamlı bir fark oluşturmamıştır. Kronik histamin veya klorfeniramin tedavisi sonucu plazma FSH seviyelerinde artış $(\mathrm{p}<0,05)$ ve LH ve testosteron $(p<0,05)$ seviyelerinde ise bir düşüş gözlenmiştir. Kronik ranitidin veya tiyoperamid tedavisi ise plazma FSH düzeylerinde bir etki oluşturmamış fakat LH ve testosteron seviyelerinde artışlara neden olmuştur $(\mathrm{p}<0,05)$. Sonuç olarak elde edilen veriler, histamin ve merkezi $\mathrm{H}_{1}$ reseptör antagonistinin uzun süreli tedavisinin, $\mathrm{LH}$ ve testosteron seviyeleri üzerinde inhibe edici etkilere sahip olduğunu göstermektedir. Bunun yanında, merkezi $\mathrm{H}_{2} \mathrm{ve}_{3} / \mathrm{H}_{4}$ reseptör antagonistleri ile yapılan kronik tedavinin üremenin düzenlenmesine katkı sağlayabileceği görülmektedir.

Anahtar Kelimeler: Histamin. Histamin antagonistleri. Merkezi Sinir Sistemi. Hipotalamo-hipofizer-gonadal aks. İntraserebroventriküler.

The Effect of Chronically Intracerebroventricular Injected Histamine and Its Antagonists on the Hypothalamic-Pituitary-Axis

\begin{abstract}
Histamine, which has neurotransmitter and neuromodulatory effects in the CNS, has a key role in regulating behavioral state, biological rhythm, body weight, energy metabolism, thermoregulation, fluid balance, stress, and reproduction. We have shown that acute central injections of histamine are effective in the hypothalamic-pituitary-gonadal (HPG) axis and that histamine central $\mathrm{H}_{1} / \mathrm{H}_{2}$ receptors mediate this effect. However, there is no explanatory information about the effects of long-term central treatments of histamine and histamine receptor antagonists in the HPG axis in studies. In the study, the effects of chronically intracerebroventricular (i.c.v.) injected histamine and its antagonists on plasma levels of gonadotropin-releasing hormone (GnRH), follicle-stimulating hormone (FSH), luteinizing hormone (LH), and testosterone hormone, which play a role in the HPG axis, were investigated. Studies were performed in male Sprague-Dawley rats. Histamine $(100 \mathrm{nmol})$, histaminergic H1 receptor antagonist chlorpheniramine (100 nmol), H2 receptor antagonist ranitidine (100 nmol), or H3/H4 receptor antagonist thioperamide $(100 \mathrm{nmol})$ was injected i.c.v. for 7 days. Chronic injection of histamine and its antagonists did not make a significant difference in plasma levels of GnRH. Chronic histamine or chlorpheniramine treatment increased plasma FSH levels $(p<0,05)$ and decreased LH/testosterone levels $(p<0,05)$. Chronic ranitidine or thioperamide treatment did not have an effect on plasma FSH levels but caused increases in LH and testosterone levels $(\mathrm{p}<0,05)$. The resulting data suggest that long-term treatment of histamine and central $\mathrm{H} 1$ receptor antagonist has inhibitory effects on $\mathrm{LH}$ and testosterone levels. Besides, it appears that chronic treatment with central $\mathrm{H}_{2}$, $\mathrm{H}_{3} / \mathrm{H}_{4}$ receptor antagonists can contribute to the regulation of reproduction.
\end{abstract}

Key Words: Histamine. Histamine Antagonists. Central Nervous System. Hypothalamic-pituitary-gonadal axis. Intraserebroventricular.

Geliş Tarihi: 06.Mayıs.2021

Kabul Tarihi: 22.Haziran.2021

Dr. Burçin ALTINBAŞ

SANKO Üniversitesi,
İncilipınar Mah. Gazimuhtarpaşa

Bulvarı No: 36

Şehitkamil / Gaziantep

Tel.: 05062305502

E-posta: altinbasburcin@gmail.com
Yazarların ORCID ID Bilgisi:

Burçin ALTINBASS: 0000-0002-9534-736X

Gökçen GÜVENÇ BAYRAM: 0000-0002-1413-3651

Murat YALÇIN: 0000-0002-5600-8162 
Hipotalamo-hipofizer-gonadal (HPG) aks, üremenin düzenlenmesinde görev yapan, birbiriyle bağlantılı nöral ve endokrin sisteminlerin humoral bir bileşeni$\operatorname{dir}^{1}$. Gonadotropin salgılatıcı hormon (GnRH) nöronları GnRH üretimi yoluyla hipofiz gonadotropları üzerindeki bir membran reseptörüne bağlanır. Böylece folikül uyarıcı hormonun $(\mathrm{FSH})$ ve luteinize edici hormonun (LH) biyosentezini ve salgılanmasını uyararak bu aksta merkezi düzenleyici bir rol oynar². Hipotalamustan GnRH salınımı her saatte bir veya günde birkaç kere olacak şekilde pulzatif olarak gerçekleşir. Koyunlarda hipotalamo-hipofizer portal sistemden direkt olarak GnRH ölçümleri, aralıklı GnRH salınımlarının, her plazma LH artışından hemen önce gerçekleştiğini göstermektedir ${ }^{3}$. Bu nedenle pulzatif bir hormon olduğundan $\mathrm{LH}$ artışlarının $\mathrm{GnRH}$ artışlarını göstermek açısından önemli bir kanıt olabileceğine inanılmaktadır. FSH ve LH testiküler fonksiyonun kontrolünde önemli rollere sahiptir. LH, testislerde leydig hücrelerinden testosteronun üretimini uyararak sırasıyla seksüel ve anabolik olayların gerçekleşmesine ve ayrıca sertoli hücreleri üzerindeki parakrin etkisiyle spermatogenezin korunmasina katkıda bulunur ${ }^{4}$. Sıçanlar ve fareler üzerinde yapılan çalışmalar, testosteronun spermatogenez için çok önemli bir role sahip olduğunu göstermektedir. Ayrıca çalışmalar testosteronun, erkek genitallerinin farkl1laşması ve büyümesi için gerekli olduğunu da ortaya koymaktadır ${ }^{4}$. FSH, ergenlik öncesi dönemde sertoli hücre çoğalmasını uyarır ve testislerin boyutu ile spermatogenezin miktarı dahil olmak üzere apoptozu kısıtlayan bir faktör olarak işlev görür ${ }^{5}$. Bu nedenle FSH'nin ana etkisi, testosteronun yanı sıra sperm üretiminin artmasına katkıda bulunmaktadır ${ }^{4}$. Testis hormonları, GnRH hormon salınımını düşürerek veya GnRH stimülasyonunda hipofizer duyarlılığı düşürerek FSH ve LH salınımını azaltır. Erkeklerde ekzojen olarak testesteron uygulanmasının, GnRH salınımının sıklığını önemli ölçüde azalttığı, FSH ve LH salınımını inhibe ettiği bildirilmiştir ${ }^{6,7}$. HPG aksın fonksiyonuna bağlı bu hormonal düzenleme, merkezi sinir sisteminde nörotransmisyon tarafından kontrol edilmektedir. Bu nörotransmisyonda şimdiye kadar arac1lığı olan birçok nörotransmitter ve/veya nöromodülatörün etkisi gösterilmiştir.

Histamin, hem sinir sisteminde bir nörotransmiter olarak hem de sinir dışı dokularda bir sinyal molekülü olarak bilinmektedir ${ }^{8}$. Mast hücrelerinin testiste periferik histaminin ana kaynağ 1 olduğu gösterilmiştir ${ }^{9}$. Testislerden salınan histaminin testiste steroidojenik aktiviteyi düzenlediği ${ }^{10}$ ve hem periferik $\mathrm{H}_{1}$ hem de $\mathrm{H}_{2}$ reseptörlerinin aracılığı ile Leydig hücre fonksiyonunun düzenlenmesinde rol oynadığı rapor edilmiştir ${ }^{11}$. $\mathrm{Bu}$ çalışmalar, periferal histaminin erkek üremesinde çok önemli bir role sahip olduğunu kanıtlamaktadır. Beyindeki histaminin ana kaynağı ise nöronlar ve mast hücreleridir ${ }^{12}$. Histaminerjik reseptörler aracılığıla bir nörotransmiter görevi gören merkezi hista- minin, enerji dengesi, susama, ağrı, öğrenme ve hafıza, dolaşım ve solunum sisteminin düzenlenmesi gibi çok sayıda merkezi sinir sistemi fonksiyonunu modüle ettiği gösterilmiştir ${ }^{12-16}$. Histaminerjik nöronların hücre gövdeleri, arka hipotalamusun tuberomamiller çekirdeğinde bulunmaktadır ${ }^{8,17}$ ve bu bölgeden çıkan histaminerjik lifler GnRH nöronlarının bulunduğu mediobazal hipotalamus ve medial preoptik alana kadar uzanmaktadır. Yine bu bölgelerde bol miktarda histaminerjik reseptörün varlığı da bildirilmiştir ${ }^{8,18,19}$. Merkezi histamin, hipotalamusta bir nörotransmiter olarak önemli bir role sahiptir ve adrenokortikotropik hormon $^{20}$, beta-endorfin ${ }^{21}$, alfa-melanosit uyarıcı hormon $^{18}$ ve prolaktin ${ }^{22}$ dahil olmak üzere hipotalamik aktivasyon yoluyla hipofiz hormonlarının nöroendokrin regülasyonunu dolaylı olarak modüle ettiği raporlanmıştır ${ }^{18,19,23,24}$. Ayrica, vazopressin ve oksitosin sekresyonlarının da histamin tarafından uyarıldığ ortaya konmuştur $^{25}$. Bunun yanında, merkezi histaminerjik reseptörlerin, özellikle merkezi $\mathrm{H}_{1}$ reseptörlerinin, histamin tarafindan düzenlenen nöroendokrin kontrole katkıda bulunduğu bilinmektedir. Çalışmalar ayrıca, histaminin HPG aksın düzenlenmesinde de görev aldığını göstermektedir. Bununla birlikte, merkezi histaminin, kadınlarda GnRH salınımının nöroendokrin kontrolünde önemli bir role sahip olduğu belirtilmektedir ${ }^{18,26}$. Çalışmalarda, histaminin kadınlarda GnRH üzerinden LH salınımını artırdığ 1 ve ayrıca östrojen kaynaklı LH salınımına $\mathrm{H}_{1}$ reseptörleri üzerinden aracılık ettiği bildirilmiştir ${ }^{18,19,27}$.

Şimdiye kadar yapılan çalışmalardan elde edilen veriler göz önüne alınarak yakın zamanda laboratuvar1mızda gerçekleştirdiğimiz bir çalışmada, akut olarak merkezi uygulanan histaminin plazma üreme hormonları (GnRH, LH, FSH, testosteron) seviyelerini artırdığını ve bu artışlara merkezi histaminin $H_{1}$ ve $H_{2}$ reseptörlerinin aracılık ettiğini gösterdik. Ortaya koyduğumuz bu sonuçlar akut olarak uygulanan egzojen histaminin etkilerinin aydınlatılmasına yönelik olup, kronik olarak uygulanan histamin veya antagonistelerinin üremede görevli hormonları nasıl etkileyeceğine dair bir kanıt üretmemektedir. Bu veriler ışığında literatürdeki bu eksiği gidermek adına bu çalışmamızda, kronik olarak merkezi yolla uygulanan histamin ve antagonistlerinin endojen histamin manipülasyonuna bağlı üreme hormonları üzerindeki olası etkilerinin aydınlatılması amaçlanmıştır.

\section{Gereç ve Yöntem}

\section{Hayvanlar}

Çalışmada Uludağ Üniversitesi Deney Hayvanları Yetiştirme ve Araştırma Merkezi'nden sağlanan 250300 g ağırlığında Sprague-Dawley türü 35 adet erişkin erkek sıçan kullanıldı. Laboratuvar ortamına adaptasyonları için sıçanlar, uygulamalardan bir hafta önce deney hayvanları merkezinden alındı ve her kafeste 3 


\section{Histamin ve Antagonistlerinin Üreme Hormonlarına Etkisi}

hayvan olacak şekilde yem ve su alımları ad libitum olarak yapıldı. Hayvanların bulunduğu odanın 1sısı 20 $24^{\circ} \mathrm{C}$, nemi \%60-70 değerlerinde sabit tutuldu. Oda 12 saat aydınlık/12 saat karanlık (07:00-19:00 saatleri arası aydınlık) döngüsüyle aydınlatıldı. Çalışmadaki tüm cerrahi ve deneysel uygulamalar, Bursa Uludağ Üniversitesi Etik Kurul Komitesi tarafindan 202103/06 Karar No ile onayland.

\section{Genel Hazırlık ve Cerrahi İşlemler}

Siçanlar, sevofluran (\%2-4 / \%100 $\left.\mathrm{O}_{2}\right)$ ile anestezi altına alındı. Anestezi altında, sıçanların kafatasları stereotaksik alete yerleştirilerek sabitlendi ve kafa derisi orta hattan kesilip kemik net bir şekilde ortaya çıkarıldı. İntraserebroventriküler (i.s.v) yolla ilaçların verilmesi için Paxinos ve Watson'un Siçan Beyin Atlası'nda belirtilen koordinatlara göre bregmanın 1,0 mm posterioru, orta hattın $1,5 \mathrm{~mm}$ lateralinde kafatasına bir delik açılarak, 22 G'lık paslanmaz çelik iğneden hazırlanmış kafatasından itibaren 4,5 mm vertikale ulaşacak olan kılavuz kanül bu delikten sokularak lateral ventriküle doğru itildi. Bu şekilde i.s.v için yerleştirilen kılavuz kanül dişçi akriliği ile kafatasına tutturuldu. Kılavuz kanül kullanılmadığında, kılavuz kanülün içinden sterilize edilmiş 28 G'lik paslanmaz çelik tıkayıcı bir kanül geçirildi. Daha sonra sıçanlar ayrı kafeslere yerleştirildi ve 1 gün boyunca anestezi etkisinin ortadan kalkması için beklenildi. Cerrahi işlemlerin ardından sıçanlar, çalışma boyunca her gün penisilin (0,3 mg / kg; kas içi) ve ayrıca buprenorfin (25 $\mu \mathrm{g} / \mathrm{kg}$; deri altı) ile tedavi edildi.

\section{Deneysel Protokol}

Çalışmada kronik olarak uygulanacak histamin ve antagonistlerinin GnRH, FSH, LH ve testosterone hormonları üzerine etkisini göstermek için hayvanlar 5 gruba ayrıldı. Her gruba ayrı bir ilaç enjeksiyonu yapıld1. Bu doğrultuda hayvanlara i.s.v yolla \%0,9'luk tuzlu su ( $5 \mu \mathrm{L} ; \mathrm{n}=7)$, histamin (100 nmol; $\mathrm{n}=7)$, histaminerjik $\mathrm{H}_{1}$ reseptör antagonisti klorfeniramin (100 nmol; $\mathrm{n}=7$ ), histaminerjik $\mathrm{H}_{2}$ reseptör antagonisti ranitidin (100 nmol; $n=7$ ) veya histaminerjik $\mathrm{H}_{3} / \mathrm{H}_{4}$ reseptör antagonisti tiyoperamid (100 nmol; n=7) enjeksiyonları yapıldı. Enjeksiyonlar 7 gün boyunca her gün sabah 09:00-10:00 saatleri arasında gerçekleştirildi. Enjeksiyonların ardından plazma hormon düzeylerinin belirlenmesi için 30. dakikada orbital sinus punksiyonu yoluyla hayvanlardan $250 \mu \mathrm{L}$ kan örneği toplandı. 7. gün deneysel çalışmaların bitiminde hayvanlara derin anestezi altında dekapitasyon işlemi uyguland.

\section{Kan Örneklerinin Toplanmast}

Siçanlar, sevofluran (\%2-4/\%100 $\left.\mathrm{O}_{2}\right)$ ile anestezi edildi. Anestezi altında, plazma hormon düzeylerinin belirlenmesi için gerekli kan örneklerinin toplanabilmesi amaciyla sıçanlardan heparinli kapiller tüpler kullanılarak orbital sinus punksiyonu yapıldı. Orbital sinus punksiyonu için kapiller tüp gözün iç açısından yavaşça çevrilerek göz yuvarlağı doğrultusunda damarlara doğru ilerletildi ve tüpün damarları yırtması sonucu oluşan kanama ile kan ince pipetin kapillaritesi sayesinde dışarı alındı. Çalışmaya 7 gün boyunca devam edildi ve hergün için aynı deneysel protokole bağlı kalınarak uygulama gerçekleştirildi. Kan toplanan bölgede meydana gelebilecek hasarlanmayı en aza indirmek için kan örnekleri, hergün aynı sıçanda farklı bir göz kullanılarak alındı. Sıçanların her birinden günlük $250 \mu \mathrm{L}$ kan toplandı. Kanlar, içerisinde EDTA içeren soğuk polipropilen tüplere alındı ve hemen ardindan $+4^{\circ} \mathrm{C}$ 'de 14,000 rpm'de 5 dakika boyunca santrifüj edilerek plazmaları ayrıldı. Ayrılan plazmalar ölçüm gününe kadar $-20^{\circ} \mathrm{C}$ 'de sakland1.

\section{Plazma GnRH, FSH, LH ve Testosteron Seviyelerinin} Belirlenmesi

GnRH (Cat.No.: E-EL-0071), LH (Cat.No.: E-ELR0026), FSH (Cat.No.: E-EL-R0391), ve testosteronun (Cat.No.: E-EL-0155), plazma konsantrasyonları, enzim immunoassay (ELISA) yöntemi kullanılarak kitlerde belirtilen talimatlara uygun şekilde sirasiyla $\mathrm{pg} / \mathrm{mL}, \mathrm{mIU} / \mathrm{mL}, \mathrm{ng} / \mathrm{mL}$ ve $\mathrm{ng} / \mathrm{mL}$ olarak ölçüldü. Tüm sıçan kitleri Elabscience Biyoteknoloji Co, Ltd. Wuhan, PCR'den satın alındı.

\section{Ilaçlar ve Intraserebroventriküler Yolla İaç Uygu- lanmasi}

Çalışmada kullanılan histamin, klorfeniramin, ranitidin ve tiyoperamid Sigma-Aldrich Co. (Deisenhofen, Almanya) firmasından temin edildi. İlaç solüsyonları deney gününde $\% 0,9^{\prime}$ luk tuzlu su içinde taze olarak hazırlandı. İlaçların dozları önceki çalışmalarımızdan seçilmiştir ${ }^{14-16,28}$.

İntraserebroventrilküler yolla ilaç enjeksiyonları toplam $5 \mu \mathrm{L}$ içinde yapıldı ve bu miktar sıvı 60 saniye boyunca yavaş infüzyon tarzında uygulandı.

\section{İstatistiksel Analiz}

Çalışmadaki tüm sonuçlar 7 siçanın "ortalama \pm standart hatası" olarak verilmiştir. Elde edilen sonuçların değerlendirilmesi iki yönlü tekrarlanan RM-ANOVA'y1 takiben Bonferroni testi ile yapılmıştır. $p<0,05$ değerler istatistiksel olarak anlamlı sayılmıştır.

\section{Bulgular}

Histamin ve Antagonistlerinin Plazma GnRH, FSH, LH ve Testosteron Hormon Seviyelerine Etkisi

Kronik olarak uygulanan merkezi enjeksiyonların 7. gününün sonunda alınan kan örneklerinden yapılan ELISA testlerinde histamin ve antagonistlerinin plazma GnRH hormon seviyesi üzerinde herhangi bir anlamlı yanıt oluşturmadığg görülmüştür (Şekil 1). 


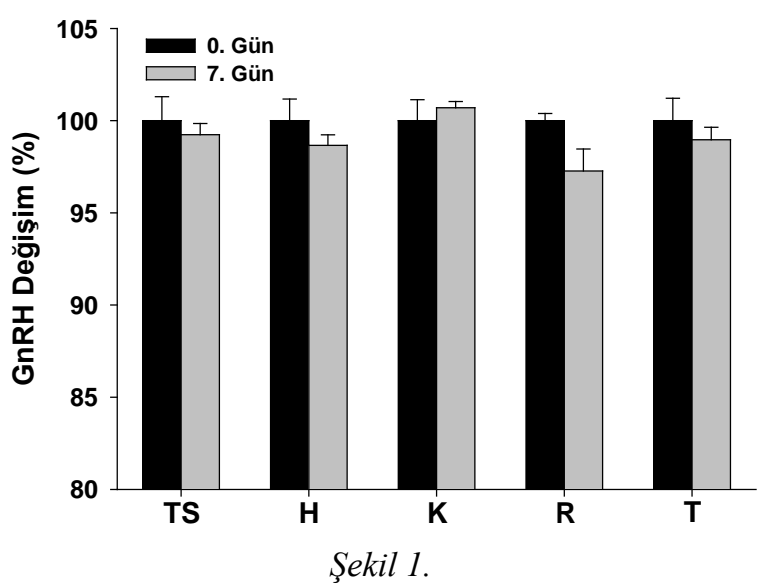

Histamin ve Merkezi Reseptör Antagonistlerinin Plazma GnRH Seviyelerine Etkisi. Siçanlar kronik olarak tuzlu su (5 $\mu$ L; i.s.v.; $n=7)$, histamin (100 nmol; i.s.v.; $n=7)$, klorfeniramin (100 nmol; i.s.v.; $n=7)$, ranitidin (100 nmol; i.s.v.; $n=7$ ) veya tiyoperamid (100 nmol; i.s.v.; $n=7$ ) ile 7 gün boyunca tedavi edildi. Sonuçlar, tedavi öncesine göre (0. gün) 7. gündeki \% değişimi göstermektedir. Veriler 7 sıçanın "ortalama土standart hatası" olarak verilmiştir. Elde edilen sonuçların değerlendirilmesi iki yönlü tekrarlanan RM-ANOVA'yı takiben Bonferroni testi ile yapılmıştır. ${ }^{*} p<0,05$, tedavi öncesi (0. gün) gruplara göre anlamlı farkı göstermektedir. i.s.v.; intraserebroventriküler, GnRH; gonadotropin salgllatıcı hormon, TS; tuzlu su, H; histamin, K; klorfeniramin, $R$; ranitidin, $T$; tiyoperamid.

7. gün sonunda kronik olarak merkezi uygulanan histamin ve merkezi $\mathrm{H}_{1}$ reseptör antagonisti klorfeniramin enjeksiyonları sonrası bazal değerlere göre plazma FSH hormonu seviyelerinde artışlar oluşmuştur (Şekil 2). Merkezi $\mathrm{H}_{2}$ reseptör antagonisti ranitidin ve $\mathrm{H}_{3} / \mathrm{H}_{4}$ reseptör antagonisti tiyoperamid enjeksiyonları ise plazma FSH hormon seviyelerinde herhangi bir değişiklik oluşturmamıştır (Şekil 2).

Plazma LH hormon seviyelerinde ise uzun süreli merkezi enjeksiyonlar sonrasında histamin ve merkezi $\mathrm{H}_{1}$ reseptör antagonisti klorfeniramin enjeksiyonları sonrasında bazal değerlere göre plazma LH hormon seviyelerinde azalma görülürken merkezi $\mathrm{H}_{2}$ reseptör antagonisti ranitidin, merkezi $\mathrm{H}_{3} / \mathrm{H}_{4}$ reseptör antagonisti tiyoperamid enjeksiyonları sonrası plazma LH hormon miktarlarında artışlar meydana gelmiştir (Şekil 3).

Yine kronik i.s.v. enjeksiyonlar sonrasında plazma testosteron seviyeleri üzerinde histamin ve $\mathrm{H}_{1}$ reseptör antagonisti klorfeniramin bazal değerlere göre plazma testosteron hormon seviyelerinde azalma oluştururken merkezi $\mathrm{H}_{2}$ reseptör antagonisti ranitidin, merkezi $\mathrm{H}_{3} / \mathrm{H}_{4}$ reseptör antagonisti tiyoperamid uygulanan gruplarda plazma testosteron hormon miktarlarında artışlar gözlemlenmiştir (Şekil 4).

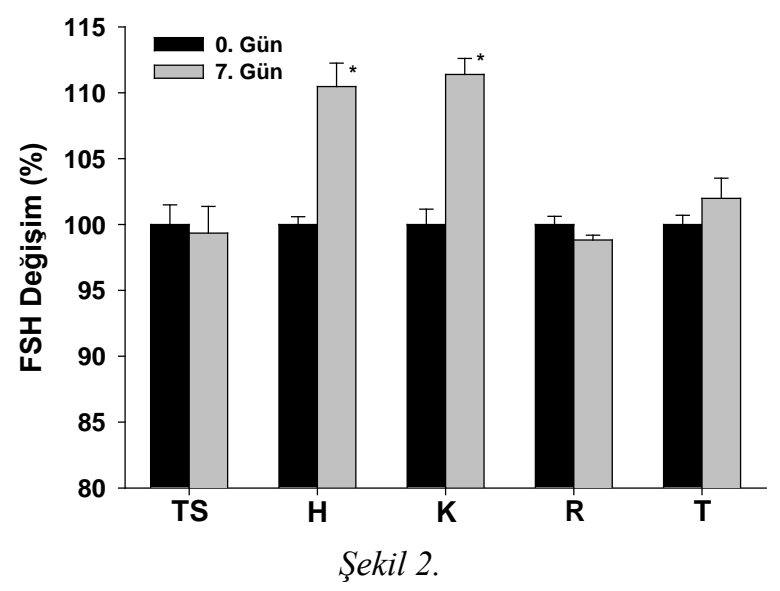

Histamin ve Merkezi Reseptör Antagonistlerinin Plazma FSH Seviyelerine Etkisi. Siçanlar kronik olarak tuzlu su (5 $\mu$ L; i.s.v.; $n=7)$, histamin (100 nmol; i.s.v.; $n=7)$, klorfeniramin (100 nmol; i.s.v.; $n=7)$, ranitidin (100 nmol; i.s.v.; $n=7$ ) veya tiyoperamid (100 nmol; i.s.v.; $n=7$ ) ile 7 gün boyunca tedavi edildi. Sonuçlar, tedavi öncesine göre (0. gün) 7. gündeki \% değişimi göstermektedir. Veriler 7 sıçanın "ortalama \pm standart hatası" olarak verilmiştir. Elde edilen sonuçların değerlendirilmesi iki yönlü tekrarlanan RM-ANOVA'y takiben Bonferroni testi ile yapılmıştır. ${ }^{*} p<0,05$, tedavi öncesi (0. gün) gruplara göre anlaml farkı göstermektedir. i.s.v.; intraserebroventriküler, FSH; folikül stimüle edici hormon, TS; tuzlu su, H; histamin, K; klorfeniramin, $R$; ranitidin, $T$; tiyoperamid.

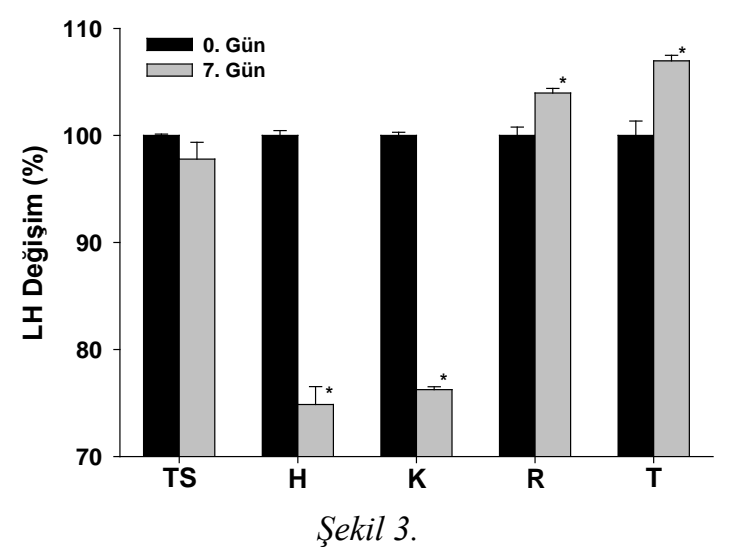

Histamin ve Merkezi Reseptör Antagonistlerinin Plazma LH Seviyelerine Etkisi. Siçanlar kronik olarak tuzlu su (5 $\mu L$; i.s.v.; $n=7)$, histamin (100 nmol; i.s.v.; $n=7)$, klorfeniramin (100 nmol; i.s.v.; $n=7)$, ranitidin (100 nmol; i.s.v.; $n=7)$ veya tiyoperamid (100 nmol; i.s.v.; $n=7$ ) ile 7 gün boyunca tedavi edildi. Sonuçlar, tedavi öncesine göre (0. gün) 7. gündeki \% değişimi göstermektedir. Veriler 7 sıçanın "ortalama \pm standart hatası" olarak verilmiştir. Elde edilen sonuçların değerlendirilmesi iki yönlü tekrarlanan RM-

ANOVA'y takiben Bonferroni testi ile yapılmıştır. ${ }^{*} p<0,05$, tedavi öncesi (0. gün) gruplara göre anlaml farkı göstermektedir. i.s.v.; intraserebroventriküler, LH; Lüteinleştirici hormon, TS; tuzlu su, H; histamin, $K$; klorfeniramin, $R$; ranitidin, $T$; tiyoperamid. 


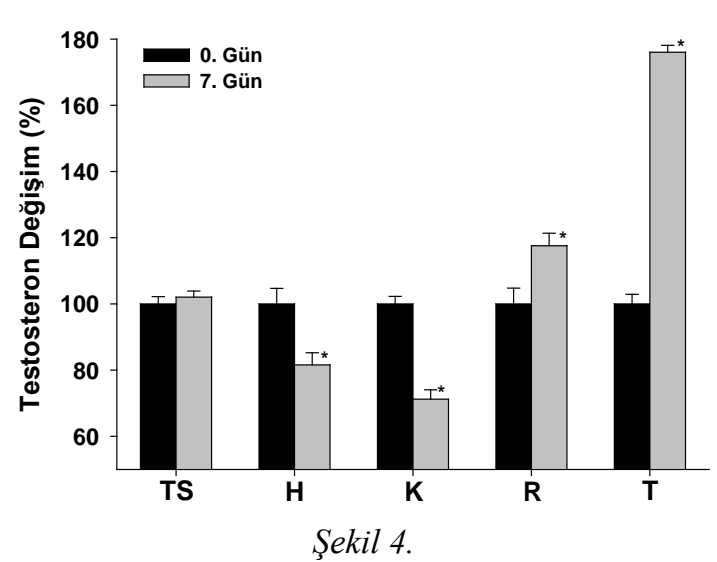

Histamin ve Merkezi Reseptör Antagonistlerinin Plazma Testosteron Seviyelerine Etkisi. Siçanlar kronik olarak tuzlu su (5 $\mu$ L; i.s.v.; $n=7)$, histamin (100 nmol; i.s.v.; $n=7)$, klorfeniramin (100 nmol; i.s.v.; $n=7)$, ranitidin (100 nmol; i.s.v.; $n=7$ ) veya tiyoperamid (100 nmol; i.s.v.; $n=7)$ ile 7 gün boyunca tedavi edildi. Sonuçlar, tedavi öncesine göre (0. gün) 7. gündeki \% değişimi göstermektedir. Veriler 7 sıçanın “ortalama \pm standart hatası" olarak verilmiştir. Elde edilen sonuçların değerlendirilmesi iki yönlü tekrarlanan RM-ANOVA'yı takiben Bonferroni testi ile yapılmıştır. ${ }^{*} p<0,05$, tedavi öncesi (0. gün) gruplara göre anlaml farkl göstermektedir. i.s.v.; intraserebroventriküler, TS; tuzlu su, H; histamin, K; klorfeniramin, $R$; ranitidin, $T$; tiyoperamid.

\section{Tartışma ve Sonuç}

Çalışmanın sonuçları, kronik olarak merkezi uygulanan histamin ve antagonistlerinin plazma GnRH hormon seviyeleri üzerinde istatistiksel olarak anlamlı bir etki oluşturmadığını ortaya koymaktadır. Diğer taraftan kronik olarak i.s.v. uygulanan histaminin ve merkezi $\mathrm{H}_{1}$ reseptör antagonisti klorfeniramin enjeksiyonları sonucunda plazma FSH hormon seviyelerinde tuzlu su grubuna göre sirasıyla \%11 ve \%12 oranında artışlar oluşurken, plazma LH seviyelerinde sirasiyla $\% 17$ ve $\% 19$, plazma testosteron seviyelerinde ise sirasıyla $\% 21$ ve $\% 31$ oranında azalmaların olduğu görülmüştür. Ayrıca, merkezi $\mathrm{H}_{2}$ reseptör antagonisti ranitidinin ve $\mathrm{H}_{3} / \mathrm{H}_{4}$ reseptör antagonisti tiyoperamidin uzun süreli merkezi enjeksiyonlarının sonucunda plazma LH seviyelerinde sirasiyla \%10 ve $\% 15$, testosteron seviyelerinde ise sirasiyla $\% 15$ ve $\% 74$ oranında artışların oluştuğu ancak plazma FSH hormon seviyelerinde herhangi bir değişiklik oluşmadığı görülmektedir.

Hipotalamik GnRH hipofizden gonadotropinlerin sentezini ve sekresyonunu kontrol eden bir dekapeptitdir $^{29}$. GnRH hormonu hipotalamik nörosekretuar hücrelerden pulzatil olarak salgilanıp hipofize özelleşmiş bir portal sistem aracılığıyla adenohipofize taşınırak burada LH ve FSH hormonlarının sentezini ve sekresyonunu uyarmaktadır ${ }^{29,30}$. Hipofiz üzerindeki oluşturduğu bu etki ile dolaylı olarak gametogenez ve steroidogenez üzerinde önemli etkiler oluşturmak$\operatorname{tad}_{12}{ }^{29}$. Testis hormonları, hem GnRH üretimini azaltarak hem de hipofiz gonadotroplarının $\mathrm{GnRH}$ stimülasyonuna duyarlılığını azaltarak gonadotropin salınımı üzerinde negatif geri bildirime neden olmaktadir. Bu durumla uyumlu olarak, egzojen testosteron uygulamasinın erkeklerde GnRH pulzasyon frekansında belirgin bir yavaşlamayı indüklediğ $i^{6}$ ve doğrudan hipofiz etkisi ile LH ve FSH salınımını engellediği gösterilmiştir ${ }^{7}$. Erkeklerde LH, leydig hücrelerinden testosteron sentezini uyarırken FSH, spermatogenezi uyarmak için sertoli ve germ hücrelerine etki etmektedir. Ayrica LH, intra-testiküler testosteron salınımını da uyararak dolaylı olarak spermatogenezi teşvik eder ${ }^{31}$. FSH, sertoli hücrelerindeki reseptörlerine ve testisteki spermatogonial membranlara bağlanır ve spermatogenezin başlangıcında ve normal sperm üretiminde önemlidir ${ }^{31}$.

Histaminin üremenin kontrolünde önemli bir role sahip olduğu bildirilmektedir ${ }^{18,19}$. Merkezi histaminin, muhtemelen seks steroidlerine olan duyarlılığı ve HPG aks ile olan etkileşimi nedeniyle, cinsiyete özgü çeşitli gelişimsel, üreme ve davranışsal beyin işlevlerinde rol oynadığı görülmektedir ${ }^{8}$. Erkek sıçanlarda yapılan çalışmalar, kastrasyonun hipotalamik histamin düzeylerini artırdığını göstermektedir ${ }^{32}$. Bunun yanı sıra, histamin eksikliği olan (HDC-KO) farelerin yüksek testis ve serum androjen seviyelerine sahip olduğu, ancak testis ağırlığının azaldı ̆̆ı ve çiftleşme davranışları ve cinsel uyarılmalarının da güçlü bir şekilde bozulduğu bildirilmiştir $^{33}$. Yakın zamanda erkek sıçanlar üzerinde yaptığımız bir çalışmada histaminin akut olarak merkezi uygulanmasının HPG aksta görevli GnRH, FSH, LH ve testosteron hormonlarının plazma seviyelerinde artışlara yol açtığını gösterdik ${ }^{34}$. Şimdiki çalışmada ise uzun süreli merkezi histamin enjeksiyonları sonucunda GnRH hormonunun plazma seviyelerinde herhangi bir değişimin olmadığını, FSH hormonunun plazma seviyelerinde ise artışların oluştuğunu ortaya koyduk. Ayrıca, kronik olarak merkezi histamin uygulaması sonrası LH ve testosteron hormonlarının plazma seviyelerinde azalmaların olduğunu gösterdik. Çalışmalarda merkezi histamin uygulamasının, ön hipofiz bezinden FSH ve LH hormonu salgılanması üzerinde doğrudan bir etkiye sahip olmadığ1, supraoptik çekirdekte lüteinleştirici hormon salgılatıcı hormon (LHRH) salgilayan nöronların uyarılması yoluyla HPG aksı uyardığı ortaya konmuştur $^{35,36}$. Bununla birlikte, bir başka çalışamada ise uzun süreli LHRH reseptör agonisti tedavisinin erkek sıçanların serum LH seviyelerinde azalmalara yol açtığ görülmüştür ${ }^{37}$. GnRH analoğunun kronik olarak uygulandığı bir başka çalışmada ise uzun süreli GnRH uyarılmasının FSH ve LH hormon üretimlerini baskıladığı gösterilmiştir ${ }^{38}$. Bu çalışmaların sonuçları, 
bulgularımızla bağlantılı olacak şekilde kronik histamin uygulamasının GnRH ve/veya LHRH reseptörlerinde duyarsızlığa neden olmuş olabileceğini düşündürmektedir. Bu durum, histaminin GnRH üzerinde anlamlı bir etki oluşturmamasını ve plazma LH ve buna bağl1 plazma testosteron seviyelerinin azalmasını açıklar niteliktedir. Antiserum enjeksiyonu yapılan sıçanlarda GnRH inhibisyonu sonucunda LH salınımının baskılandığı fakat GnRH inhibisyonunun FSH üzerinde herhangi bir etkiye yol açmadığı bildirilmiştir $^{39,40}$. Bu çalışmanın yanında, LH salınımının tamamen $\mathrm{GnRH}$ salgılanmasına bağlı olduğu bilgisini güçlendiren ve GnRH'nin, FSH salımının tek düzenleyicisi olmayabileceğini düşündüren çalışmalar da mevcuttur ${ }^{41,42}$. Yine LHRH'nin de FSH salgisının sürdürülmesinde etkili olduğu bildirilmektedir. $\mathrm{Bu}$ çalışmanın sonucu da, LHRH'nin FSH salgılanmasında gerekli olduğunu ancak LHRH'nin de FSH salınımının tek düzenleyicisi olmayabileceğine işaret etmektedir ${ }^{43}$. Bu nedenden dolayı FSH salınımını seçici olarak düzenleyen ayrı bir FSH salgılatan hormonun varlığı da düşünülebilir. Bu çalışmalar da, yine kronik histamin uygulanmasının, plazma FSH hormonu seviyelerinde oluşan artışların kendi reseptörleri aracılığıyla yada başka bir mekanizmayı aktif etmesi yoluyla olabileceğini göstermektedir. Ayrıca, mast hücreleri ve bazofillerden salınan histamin, rinit, ürtiker, astım ve sistemik anafilaksi dahil tüm alerjik hastalıkların patofizyolojisinde önemli bir rol oynamaktadır ${ }^{44}$. Astım/rinitli hastalarda yapılan çalışmalar bu hastalarda düşük testosteron seviyelerinin olduğunu göstermektedir ${ }^{45}$. Bu çalışmalar da yine çalışmamızla uyumlu olarak uzun süreli histamin tedavisinin LH ve testosteron hormonları üzerindeki baskılayıcı etkiyi açıklayabilir.

Çalışmamızın diğer aşamasında kronik uygulanan histamin antagonistlerinin GnRH, FSH, LH ve testosteron üzerine olan etkileri araştırılmıştır. Daha önce yaptığımız çalışmanın sonucunda histaminin akut enjeksiyonunun GnRH, FSH, LH ve testosteron hormonları üzerinde oluşturduğu artışlara histaminin merkezi $\mathrm{H}_{1}$ ve $\mathrm{H}_{2}$ reseptörlerinin aracılık ettiğini rapor ettik $^{34}$. Bu çalıșmada ise kronik olarak uygulanan histaminin merkezi $\mathrm{H}_{1}$ reseptörlerinin, kronik histamin tedavisiyle aynı sonuçlara sahip olduğu verisine ulaştık. Çalışmamızda da klorfeniraminin reseptör bağlayıcı etkisiyle endojen histaminin bu reseptörlere bağlanamadığı ve buna bağlı olarak GnRH salınımını uyaramadığ1 ve paralelinde LH ve testosteron seviyelerinde düşüşlerin yaşandığı düşünülebilir. FSH'nin de önceden belirtildiği gibi salınımında birkaç faktörün olabileceğinin ortaya konması ${ }^{41,42}$, uzun süreli klorfeniramin enjeksiyonu sonrası görülen FSH artışlarında klorfeniramin bağımlı ve/veya bağımsız etkinin olabileceğini düşündürmektedir. Ayrıca, klorfeniraminin beyinde merkezi $\mathrm{H}_{1}$ reseptörlerini yüksek oranda bloke etmesi ${ }^{44} \mathrm{LH}$ ve testosteron hormonlarının salınımındaki azalmayı açıklayabilmekte- dir. Bunun yanında, hamilelik sırasında, nazal alerjisi olan deneklerde nazal epitel tabakasından alınan örneklerde histaminin $\mathrm{H}_{1}$ reseptörünün mRNA seviyesinde artışların olduğu gösterilmektedir. Histaminin, hedef organları uyarma kabiliyetinin önlenmesi amacıyla klinikte $\mathrm{H}_{1}$ reseptör antagonistleri sıç̧a kullanılmaktadır. $\mathrm{H}_{1}$ reseptör antagonistleri, histaminin $\mathrm{H}_{1}$ reseptörü ile etkileşimini rekabetçi bir şekilde inhibe eder, böylece histaminin vazodilatör etkilerini ortadan kaldırarak ödem, alevlenme ve kabarıklığın oluşumunu önler ${ }^{46}$. Bu tip hastalıklara sahip kişilerin tedavide uzun süreli $\mathrm{H}_{1}$ reseptör antagonisti kullanmaları kişilerin üreme faaliyetlerinde aksaklıkların oluşmasına yol açabilir. Son olarak ranitidin ve tiyoperamidin uzun süreli tedavilerinde GnRH ve FSH seviyelerinde anlamlı bir değişimin olmadığını, LH ve testosteron seviyelerinde ise artışların oluştuğunu ortaya koyduk. Yapılan birkaç çalışmada erkek hastalara intravenöz veya oral yolla kısa veya uzun süreli yapılan ranitidin tedavisinin HPG aksta görevli üreme hormonlarının plazma seviyelerinde herhangi bir değişikliğe yol açmadığı ortaya konmaktadır ${ }^{47,48}$. Bu yüzden, GnRH'nin aralıklı salınıma sahip olması ${ }^{3,29,30}$ nedeniyle ranitidin enjeksiyonları sonrası GnRH seviyelerinde bir değişimin olmadığı düşünülebilir. Fakat LH ve testosteron hormon seviyelerindeki artışların muhtemelen GnRH salınımı sonrası ${ }^{41,42}$ ortaya çıktığı yada ranitidinin merkezi tedavisinin bir etkisi olduğu kanısına varmak mümkündür. Yine aynı ajanın FSH salınımında da anlamlı bir etkisinin olmaması FSH'nin de salınımının farklı faktörlere bağlı ${ }^{41-43}$ olmasından dolayı olabileceği düşünülebilir. Son olarak, merkezi sinir sistemi içerisinde histaminin $\mathrm{H}_{3} / \mathrm{H}_{4}$ reseptörlerinin etkinliğinin araştırıldığı çalışmalarda, $\mathrm{H}_{3} / \mathrm{H}_{4}$ reseptörlerinin endojen histaminin inhibisyonunda görevli otoreseptörler olarak çalıştıkları görülmektedir ${ }^{49,50}$. Bununla birlikte, $\mathrm{H}_{3} / \mathrm{H}_{4}$ reseptör antagonistlerinin intrahipotalamik ve subkutan enjeksiyonlarının hipotalamik histamin salınımını artırdı $\breve{g}_{1}$ da gösterilmiştir ${ }^{51}$. Bu veriler 1şı ğında, kronik tioperamid enjeksiyonları sonrası LH'de oluşan artış ile testosteronda oluşan \%74'lük yüksek orandaki artışların önceki çalışmalarla uyum gösterdiği görülmektedir.

Çalışmanın sonuçları, uzun süreli merkezi histamin tedavisinin $\mathrm{LH}$ ve testosteron hormonları üzerinde inhibe edici etkilere neden olduğunu ortaya koymaktadır. Ayrıca, çalışmada kullanılan $\mathrm{H}_{1}$ reseptör antagonisti klorfeniraminin, merkezi histamin reseptörlerinde oluşturduğu blokaja bağlı LH ve testosterone hormonlarının salınımında etki gösteremediği, $\mathrm{H}_{2}$ reseptör antagonisti ranitidinin muhtemelen HPG aksta etkili olmadığ ve $\mathrm{H}_{3} / \mathrm{H}_{4}$ reseptör antagonisti tiyoperamidin ise otoreseptör özelliğine bağlı olarak üreme hormonlarından özellikle $\mathrm{LH}$ ve testosteron hormon salınımının uyarılmasında etkili olduğu görülmektedir. 


\section{Histamin ve Antagonistlerinin Üreme Hormonlarına Etkisi}

Etik Kurul Onay Bilgisi:

Onaylayan Kurul: Bursa Uludağ Üniversitesi Hayvan Deneyleri

Yerel Etik Kurulu

Onay Tarihi: 16.03 .2021

Karar No: 2021-03/06

\section{Arastırmacı Katkı Beyanı:}

Fikir ve tasarım; M.Y., B.A.; Veri toplama ve işleme M.Y., B.A., G.G.B.; Analiz ve verilerin yorumlanması M.Y., B.A., G.G.B.;

Makalenin önemli bölümlerinin yazılması M.Y., B.A.

Çıkar Çatışması Beyanı:

Makale yazarının çıkar çatışması beyanı yoktur.

\section{Kaynaklar}

1. Fink G. 60 YEARS OF NEUROENDOCRINOLOGY: MEMOIR: Harris' neuroendocrine revolution: of portal vessels and self-priming. J Endocrinol 2015;226(2).

2. Amory JK, Bremner WJ. Regulation of testicular function in men: implications for male hormonal contraceptive development. J Steroid Biochem Mol Biol 2003;85,357-361.

3. Clarke I, Cummins J. The temporal relationship between gonadotropin releasing hormone $(\mathrm{GnRH})$ and luteinizing hormone (LH) secretion in ovariectomized ewes. Endocrinology 1982;111,1737-9.

4. Huhtaniemi I. A short evolutionary history of FSH-stimulated spermatogenesis. Hormones (Athens) 2015;14,468-78.

5. Sharpe RM, McKinnell C, Kivlin C, Fisher JS. Proliferation and functional maturation of Sertoli cells, and their relevance to disorders of testis function in adulthood. Reproduction 2003;125,769-784.

6. Matsumoto AM, Bremner WJ. Modulation of pulsatile gonadotropin secretion by testosterone in men. J Clin Endocrinol Metab 1984;58,609-14.

7. Sheckter CB, Matsumoto AM, Bremner WJ. Testosterone administration inhibits gonadotropin secretion by an effect on the human pituitary. J Clin Endocrinol Metab 1989;68,397401.

8. Haas HL, Sergeeva OA, Selbach O. Histamine in the Nervous System. Physiol Rev 2008;88, 1183-241.

9. Badr FM. Effect of sexual maturation and androgens on prostaglandin levels in tissues of the male reproductive system in mice. Endocrinology 1976;98,1523-7.

10. Mayerhofer A, Bartke A, Amador AG, Began T. Histamine affects testicular steroid production in the golden hamster. Endocrinology 1989;125,2212-4.

11. Khan UW, Rai U. Differential effects of histamine on Leydig cell and testicular macrophage activities in wall lizards: precise role of H1/H2 receptor subtypes. J Endocrinol 2007;194,441-8.

12. Brown RE, Stevens DR, Haas HL. The physiology of brain histamine. Prog Neurobiol 2001;63,637-72.

13. Fogel WA, Stasiak A, Lewinski A, Maksymowicz M, Jochem J. Satiety signalling histaminergic system system and brain-gut peptides in regulation of food intake in rats with portocaval anastomosis. J Physiol Pharmacol 2008;59,135-44.

14. Yalcin M, Savci V, Jochem J. Involvement of the cholinergic system in the central histamine-induced reversal of critical haemorrhagic hypotension in rats. J Physiol Pharmacol 2009;60,133-7.

15. Altinbas B, Yilmaz MS, Savci V, Jochem J, Yalcin M. Centrally injected histamine increases posterior hypothalamic acetylcholine release in hemorrhage-hypotensive rats. Auton Neurosci 2015;187,63-9.

16. Altinbas B, Guvenc G, Erkan LG, Ilhan T, Niaz N, Yalcin M. Histamine restores hemorrhage induced hypotension by activa- ting cholinergic neurons in nucleus tractus solitarius. Brain Res 2016;1649,132-40.

17. Schwartz JC, Arrang JM, Garbarg M, Pollard H, Ruat M. Histaminergic transmission in the mammalian brain. Physiol Rev 1991;71,1-51.

18. Knigge U, Warberg J. Neuroendocrine functions of histamine. Agents Actions Suppl 1991a;33,29-53.

19. Knigge U, Warberg J. The role of histamine in the neuroendocrine regulation of pituitary hormone secretion. Acta Endocrinol 1991b;124,609-19.

20. Kjaer A, Knigge U, Bach FW, Warberg J. Histamine- and stress-induced secretion of ACTH and beta-endorphin: involvement of corticotropin-releasing hormone and vasopressin. Neuroendocrinology 1992;56,419-28.

21. Mitsuma T, De-Heng S, Nogimori T, Chaya M, Hirooka Y, Ohtake K. Effect of histamine and its blockers on plasma betaendorphin-like immunoreactivity in rats. Endocrinol Exp 1987;21,95-102.

22. Knigge UP. Histaminergic regulation of prolactin secretion. Dan Med Bull 1990;37,109-24.

23. Bugajski J, Janusz Z. Central histaminergic stimulation of pituitary-adrenocortical response in the rat. Life Sci 1983;33,1179-89.

24. Kjaer A, Larsen PJ, Knigge U, Warberg J. Histaminergic activation of the hypothalamic-pituitary-adrenal axis. Endocrinology 1994;135,1171-7.

25. Radacs M, Galfi M, Juhasz A, Varga C, Molnar A, Laszlo F, Laszlo FA. Histamine-induced enhancement of vasopressin and oxytocin secretion in rat neurohypophyseal tissue cultures. Regul Pept 2006;134,82-8.

26. Lee AW, Devidze N, Pfaff DW, Zhou J. Functional genomics of sex hormonedependent neuroendocrine systems: specific and generalized actions in the CNS. Prog Brain Res 2006;158,24372.

27. Noris G, Hol D, Clapp C, Martinez- dela-Escalera G. Histamine directly stimulates gonadotropin-releasing hormone secretion from GT1-1 cells via H1 receptors coupled to phosphoinositide hydrolysis. Endocrinology 1995;136,2967-74.

28. Jochem J, Savci V, Filiz N, Rybus-Kalinowska B, Fogel WA, Yalcin M. Involvement of the histaminergic system in cytidine 5'-diphosphocholine-induced reversal of critical haemorrhagic hypotension in rats. J Physiol Pharmacol 2010;61,37-43.

29. King JA, Millar RP. Evolutionary aspects of gonadotropinreleasing hormone and its receptor. Cell Mol Neurobiol 1995;15:5-23.

30. dAnglemont-de-Tassigny X, Fagg LA, Carlton MBL, Colledge WH. Kisspeptin Can Stimulate Gonadotropin-Releasing Hormone (GnRH) Release by a Direct Action at GnRH Nerve Terminals. Endocrinology 2008;149,3926-32.

31. Matsumoto AM, Karpas AE, Bremner WJ. Chronic human chorionic gonadotropin administration in normal men: evidence that follicle stimulating hormone is necessary for the maintenance of quantitatively normal spermatogenesis in man. $\mathrm{J}$ Clin Endocrinol Metab 1986;62,1184-92.

32. Orr EL, Quay WB. The effects of castration on histamine levels and 24 hour rhythm in the male rat hypothalamus. Endocrinology 1975;97,481-4.

33. Par G, Szekeres-Bartho J, Buzas E, Pap E, Falus A. Impaired reproduction of histamine deficient (histidine-decarboxylase knockout) mice is caused predominantly by a decreased male mating behavior. Am J Reprod Immunol 2003;50,152-8.

34. Niaz N, Guvenc G, Altinbas B, Toker MB, Aydin B, UdumKucuksen D, et al. Intracerebroventricular injection of histamine induces the hypothalamic-pituitary-gonadal axis activation in male rats. Brain Res 2018;1699,150-7.

35. Miyake A, Ohtsuka S, Nishizaki T, Tasaka K, Aono T, Tanizawa $\mathrm{O}$, et al. Involvement of $\mathrm{H} 1$ histamine receptor in basal 


\section{B. Altınbaş, ark.}

and estrogen-stimulated luteinizing hormone-releasing hormone secretion in rats in vitro. Neuroendocrinology 1987;45,191-6.

36. Ojeda SR, McCann SM. Control of LH and FSH release by LHRH: influence of putative neurotransmitters. Clin Obstet Gynaecol 1978;5,283-303.

37. Horvath JE, Bajo AM, Schally AV, Kovacs M, Herbert F, Kate G. Effects of long-term treatment with the luteinizing hormonereleasing hormone (LHRH) agonist Decapeptyl and the LHRH antagonist Cetrorelix on the levels of pituitary LHRH receptors and their mRNA expression in rats. Proc Natl Acad Sci USA 2002;99,15048-53.

38. Swerdloff RS, Heber D, Bhasin S, Rajfer J. Effect of GnRH superactive analogs (alone and combined with androgen) on testicular function in man and experimental animals. J Steroid Biochem 1983;19,491-7.

39. Culler MD, Negro-Vilar A. Pulsatile follicle-stimulating hormone secretion is independent of luteinizing hormone-releasing hormone (LHRH): pulsatile replacement of LHRH bioactivity in LHRH immunoneutralized rats. Endocrinology 1987;20,2011-21.

40. Kovacs M, Koppan M, Mezo I, Teplan I, Flerko B. Antiovulatory doses of antagonists of LH- RH inhibit LH and progesterone but not FSH and estradiol release. J Neuroendocrinol 1993;5,603-8.

41. Lumpkin MD, DePaolo LV, Negro-Vilar A. Pulsatile release of follicle-stimulating hormone in ovariectomized rats is inhibited by porcine follicular fluid (Inhibin). Endocrinology 1986;114,201-6.

42. Mizunuma H, Samson WK, Lumpkin MD, Moltz JH, Fawcet CP, McCann SM. Purification of a bioactive FSH-releasing factor (FSHRF). Brain Res Bull 1983;10,623-9.

43. Culler MD, Negro-Vilar A. Evidence that pulsatile follicle stimulating hormone secretion is independent of endogenous luteinizing hormone-releasing hormone. Endocrinology 1986;118,609-12.

44. Church MK, Casale TB. Principles of pharmacotherapy. Allergy 2012;147-69.

45. Lokaj-Berisha V, Gacaferri-Lumezi B, Berisha N, Gashi-Hoxha S. A Pilot Study on BMI, Serum Testosterone and Estradiol Levels in Allergic Male Patients. Open Access Maced J Med Sci 2015;3,595-600.

46. Habibi A, Riley ET. Antihistamines: H1- and H2- Blockers. Complications in Anesthesia 2007;92-3.

47. Knigge U, Dejgaard A, Wollesen F, Ingerslev O, Bennett P, Christiansen PM. The acute and long term effect of the H2receptor antagonists cimetidine and ranitidine on the pituitarygonadal axis in men. Clin Endocrinol (Oxf) 1983;18,307-13.

48. Corinaldesi R, Pasquali R, Paternico A, Stanghellini V, Paparo GF, Ricci Maccarini M, et al. Effects of short- and long-term administrations of famotidine and ranitidine on some pituitary, sexual and thyroid hormones. Drugs Exp Clin Res 1987; 13,647-54.

49. Prast H, Fischer HP, Prast M, Philippu A. In vivo modulation of histamine release by autoreceptors and muscarinic acetylcholine receptors in the rat anterior hypothalamus. NaunynSchmiedeberg's Arch Pharmacol 1994;350,599-604.

50. Arrang JM, Garbarg M, Lancelot JC, Lecomte JM, Pollard H, Robba M, et al. Highly potent and selective ligands for histamine H3 receptors. Nature 1987;327,117-25.

51. Jansen FP, Mochizuki T, Yamamoto Y, Timmerman H, Yamatodani A. In vivo modulation of rat hypothalamic histamine release by the histamine $\mathrm{H} 3$ receptor ligands, immepip and clobenpropit. Effects of intrahypothalamic and peripheral application. Eur J Pharmacol 1998;362,149-55. 